\title{
Risk Analysis of Gas Pipeline Relocation in Northern Sumatera
}

\author{
Reynandi Rifky ${ }^{1}$, Abdul Wahid ${ }^{2}$ \\ Student, Department of Chemical Engineering, University of Indonesia, Jakarta, Indonesia ${ }^{1}$ \\ Lecturer, Department of Chemical Engineering, University of Indonesia, Jakarta, Indonesia ${ }^{2}$
}

\begin{abstract}
The development of new infrastructure aimed to stimulating economic growth, often disrupt existing facilities. The construction of toll roads in the Northern Sumatra, for example, passes through a 12 inches transmission gas pipeline that connects Kawasan Industri Medan (KIM) - Kawasan Ekonomi Khusus (KEK) Sei Mangkei. This causes crossings at six location points and results in additional loads on the gas pipelines which were not previously calculated. Therefore it is necessary to relocate the gas pipeline. However, there are many risks that might occurred in relocating gas pipeline. Hence the risk assessment must be considered to find out which risk variables have the highest influence on this gas pipeline relocation. The result of risk analysis indicates this gas pipeline relocation as a whole has moderate risk status, with safety \& security risk category relating to safety in doing work, both during construction and operation, being the risk category that has the highest risk. There is a potential loss from gas sales and distribution of USD 55.223 per year if gas pipeline is not relocated, by assuming there is only one damage occurs per year at each of crossing points (six crossing points) and requires seven days repaired time of each. And also there is a potential loss of USD 320.132 if gas pipeline is relocated but the risks are not mitigated. Although risk mitigation requires an additional cost of USD 45,596 to mitigate 23 risk variables, however these costs can provide a potential cost savings of USD 274.536 compared to if the risks in this gas pipeline relocation are not mitigated.
\end{abstract}

Keywords: Gas Pipeline Relocation, KEK Sei Mangkei, Risk Analysis

\section{INTRODUCTION}

In order to boost economic growth in Indonesia, the constructions of new infrastructures such as dams, bridges, roads, railways, power plants, and ports are widely carried out [1]. However, these constructions often raises new problems, such as the overlapping land in Northern Sumatra between the construction of a toll road connecting Medan - Kualanamu - Tebing Tinggi (MKTT) and a gas pipeline that connecting Kawasan Industri Medan (KIM) - Kawasan Ekonomi Khusus (KEK) Sei Mangkei. This can occur due to lack of coordinator between toll road and gas pipeline manager. The land that had previously been cleared for toll road construction, at the same time it is also used for gas pipelines construction. This resulted in crossings at six location points and imposing additional loads on gas pipelines that were not previously calculated. A pipeline that transports hazardous gases raises no health hazards to person or environment near the pipeline as long as the pipeline is properly maintained its integrity and does not release gas into the environment [2]. But on the other hand, a pipeline failure that results in gas release, generates risks to people and environment in the vicinity of the release point because of the flammable, explosive, and toxic properties of the gas [3]. An action to install temporary protection for gas pipelines by using concrete boxes and temporary support have been carried out, however by considering safety factor, as well as the development of gas pipeline and toll road in the future, then the relocation of gas pipelines was carried out. The relocated gas pipeline is 12 inches in diameter and the length of relocation is about $2.5 \mathrm{~km}$. Relocation was carried out in a conventional and auger boring method.

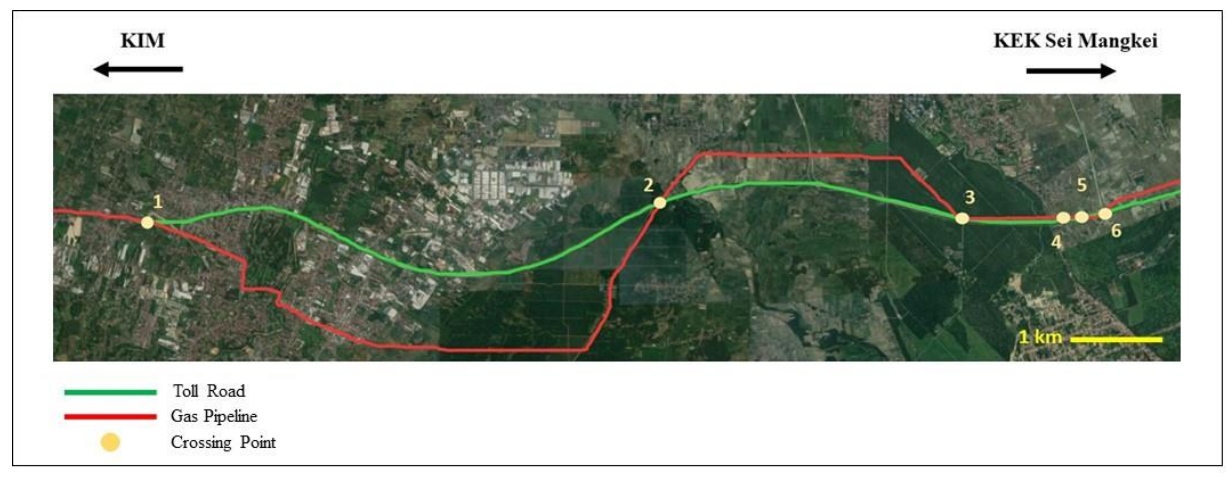

Fig. 1 Crossing points location 


\section{International Advanced Research Journal in Science, Engineering and Technology}

Vol. 8, Issue 5, May 2021

\section{DOI: 10.17148/IARJSET.2021.8523}

Oil and gas projects are very complex, risky and have challenges that continue to increase every day because of the various problems that faces. For instance in gas pipeline relocation. There are many risks can occur in relocating gas pipeline that can result in failure of the gas pipeline. Miao and Zhao [4] divided the main causes of pipe failure into four groups : third-party damage, corrosion, design and construction errors, and improper operating condition. In general, risks associated with gas pipeline projects may be classified into risk during construction and risk during operation [5]. Risks during construction are time-prone. These generally relates to the implementation of work processes, availability of materials, labor, budget, timeframes, accidents, law and environmental. For example, gas pipeline relocation in East Java, the addition of material with a long delivery time during the construction of the gas pipeline is the highest risk in that project. This condition causes additional time which can delay project completion and have an impact on project finances [6]. Another example of risk during gas pipeline construction is resistance from local residents or land owners. Bogucki and Polonski [7] in their paper explain that community rejection risk of high pressure gas pipeline construction has a high risk. It can affect the project completion time. To overcome this condition, it is necessary to carry out information campaign before construction started. In operation, the risks are slightly different, where more emphasizing on safe and smooth operation/functioning of pipeline. Several previous studies, explain the risk of terrorism \& sabotage is the highest risk in gas pipeline operations $[8,9]$. In Indonesia terrorism risk on gas pipeline has occurred in Gading Serpong in 2011, where there were plans for suicide bombing in the vicinity of a gas pipeline. Fortunately, the plan was thwarted. In addition, the risk of damage to gas pipelines is also a risk that often occurs and needs attention in gas pipeline operations [10]. For example in Nigeria, pipeline ruptures is the most common incident causing oil spill, fires and explosion. These occur due to corrosion, lack of routine inspections, operational failures and natural disaster [11]. The emergence of risk cannot be avoided. Risk can be defined as an opportunity for an occurrence or a failure that can lead to a negative consequence in the form of loss, damage, injury, and even death to the personnel, facilities and the environment [12]. Therefore, in order to maintain a safe and secure construction and operation circumstances, monitoring and evaluation must be carried out continuously [13].

Risk can be overcome by carrying out risk management. For effective risk management, risk classification is paramount. There are many kinds of risk classification have been made so far [14]. Risk can also be managed by referring to the concept of risk assessment. Risk assessment is a quantification process to determine what kind of risks that may occur in a system. To get the concept of quality and good management from a process, it is necessary to quantify the involved factors. The size or value obtained will determine the size and risk of loss that may arise from a process [15]. A common method used for assessing risk is risk matrices. These are typically $5 \times 5$ matrices, and each block of the matrix represents some level of risk [16]. Risk matrix is defined as a mechanism to characterizing and ranking risk, which has several categories of probability and impact for its rows and columns [17, 18]. Risk matrices can help in determining the risk status by multiplying the probability and impact values, to find out whether the risk has low, medium or high status [19].

\begin{tabular}{|c|c|c|c|c|c|c|c|c|c|c|}
\hline Probabillty & \multicolumn{5}{|c|}{ Threats } & \multicolumn{5}{c|}{ Opportunitles } \\
\hline 0.90 & 0.05 & 0.09 & 0.18 & 0.36 & 0.72 & 0.72 & 0.36 & 0.18 & 0.09 & 0.05 \\
\hline 0.70 & 0.04 & 0.07 & 0.14 & 0.28 & 0.56 & 0.56 & 0.28 & 0.14 & 0.07 & 0.04 \\
\hline 0.50 & 0.03 & 0.05 & 0.10 & 0.20 & 0.40 & 0.40 & 0.20 & 0.10 & 0.05 & 0.03 \\
\hline 0.30 & 0.02 & 0.03 & 0.06 & 0.12 & 0.24 & 0.24 & 0.12 & 0.06 & 0.03 & 0.02 \\
\hline 0.10 & 0.01 & 0.01 & 0.02 & 0.04 & 0.08 & 0.08 & 0.04 & 0.02 & 0.01 & 0.01 \\
\hline & 0.05 & 0.10 & 0.20 & 0.40 & 0.80 & 0.80 & 0.40 & 0.20 & 0.10 & 0.05 \\
\hline
\end{tabular}

Fig. 2 Probability-impact matrices

Another method that can be used is sensitivity analysis, which is a quantitative risk analysis that is used to assist in determining which risks have the highest influence on the project. Sensitivity analysis makes it possible to forecasts using real historical data by studying all possible variables and outcomes. The results of this sensitivity analysis allow decision makers to identify where they can make improvements in the future. So that the decisions taken become more precise and reliable [20]. However, the results of this analysis are not completely accurate. 


\section{International Advanced Research Journal in Science, Engineering and Technology}

Vol. 8, Issue 5, May 2021

DOI: $10.17148 /$ IARJSET.2021.8523

\section{METHODOLOGY}

The research procedure scheme can be seen in Figure 3.

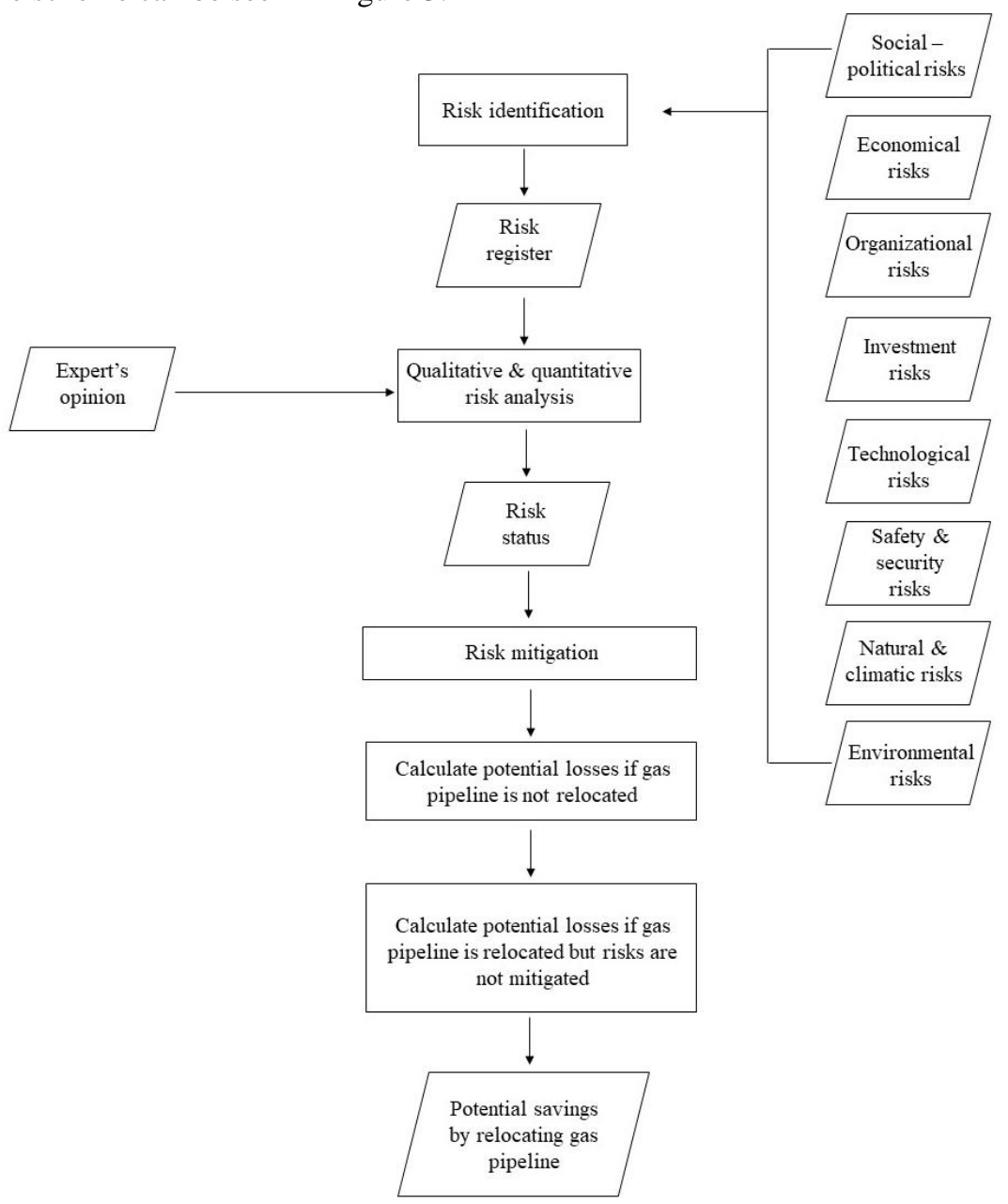

Fig. 3 Research procedure scheme

\section{RESULT}

A. Risk Analysis and Mitigation

Risk identification is carried out and obtained 44 risk variables from eight risk categories. By referring to probability impact matrices, there are 6 risk variables with low status, 29 risk variables with moderate status, and 9 risk variables with high status.

TABLE I RISK VARIABLES AND RISK STATUS

\begin{tabular}{|c|c|c|c|c|c|}
\hline \multirow{2}{*}{ No } & \multirow{2}{*}{ Risk Category } & \multicolumn{2}{|r|}{ Risk Event } & \multirow{2}{*}{ Risk Status } & \multirow{2}{*}{ Author } \\
\hline & & No & Variable & & \\
\hline \multirow{4}{*}{1} & \multirow{4}{*}{ Social - Political } & 1 & Delays in licensing process & Moderate & [5] \\
\hline & & 2 & Demonstrations and objections from residents & Moderate & [5] \\
\hline & & 3 & Riot and area closure at the project site & Moderate & [5] \\
\hline & & 4 & $\begin{array}{l}\text { Non-Governmental Organization opposing and } \\
\text { provoking residents }\end{array}$ & Moderate & {$[21]$} \\
\hline \multirow{2}{*}{2} & \multirow{2}{*}{ Economical } & 5 & Inflation and rising prices of the material & Moderate & {$[5]$} \\
\hline & & 6 & Changes in economic policy & Moderate & {$[5]$} \\
\hline \multirow{4}{*}{3} & \multirow{4}{*}{ Organizational } & 7 & Breach in contractual relationship & Moderate & [5] \\
\hline & & 8 & Incompetent of the labour & Moderate & [5] \\
\hline & & 9 & Contractor cannot meet the material delivery time & Moderate & [5] \\
\hline & & 10 & Delay in completing EPC stages & Moderate & {$[5]$} \\
\hline
\end{tabular}


International Advanced Research Journal in Science, Engineering and Technology

Vol. 8, Issue 5, May 2021

DOI: $10.17148 / I A R J S E T .2021 .8523$

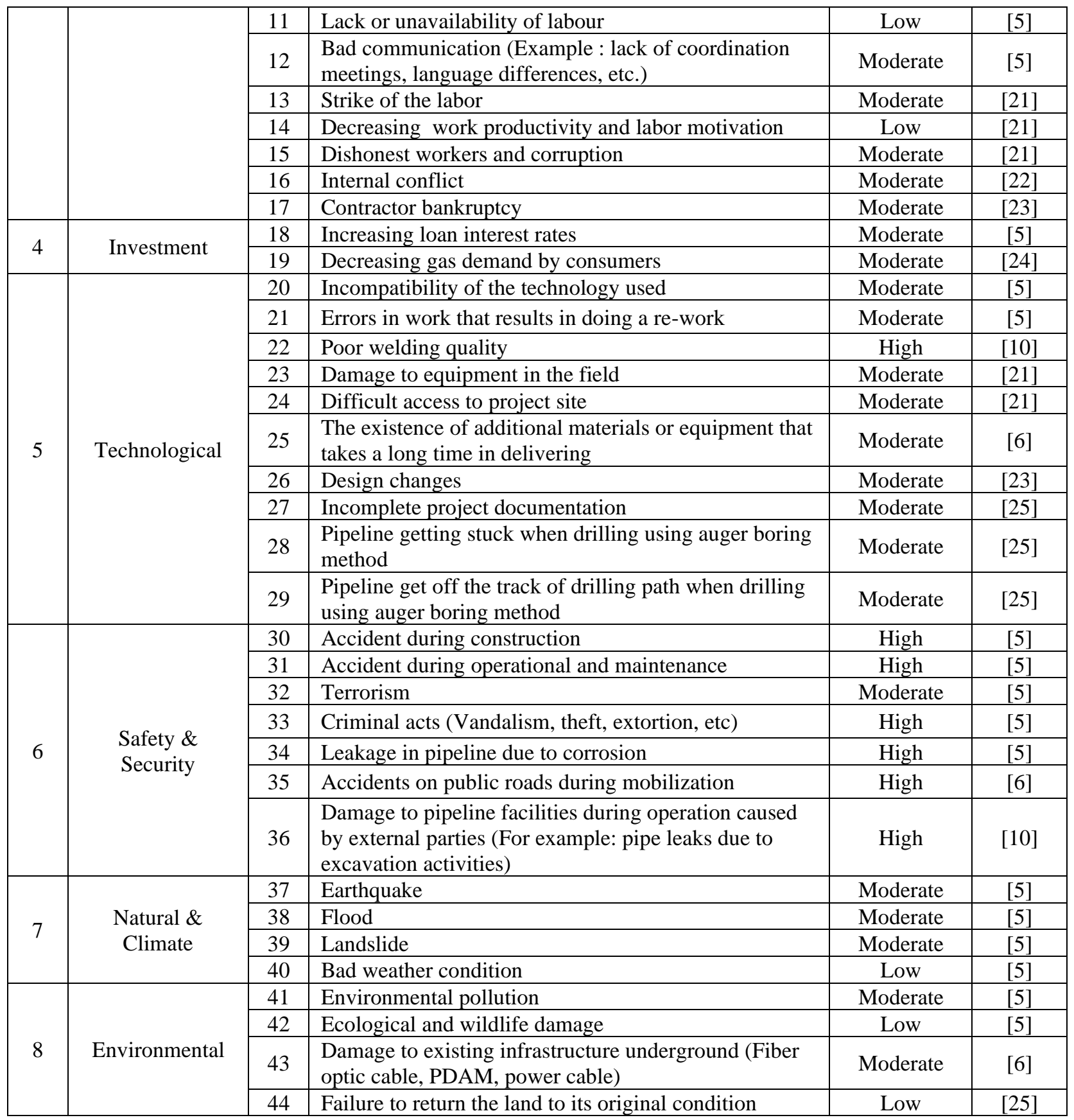

This gas pipeline relocation, overall, has a risk distribution value between 0.097 to 0.107 , with a value at $85 \%$ certainty level is 0.104 . If referring to the probability-impact matrices at Figure 2, then this gas pipeline relocation has moderate risk status. It is necessary to mitigate the risks so the status can be lowered to low. By using sensitivity analysis, there are 23 risk variables that need to be mitigated. Risk mitigation certainly requires additional cost. By discussing with experts, the estimated cost required to mitigate 23 risk variables in Table 2 is USD 45.596.

TABLE III MITIGATION ACTION

\begin{tabular}{|c|l|l|}
\hline Risk Category & Risk Variable & \multicolumn{1}{c|}{ Mitigation Action } \\
\hline $\begin{array}{c}\text { Social - } \\
\text { Political }\end{array}$ & $\begin{array}{l}\text { Demonstrations and } \\
\text { objections from } \\
\text { residents }\end{array}$ & $\begin{array}{l}\text { - Conducting an intensive approach, socializing, and educating to the } \\
\text { local community }\end{array}$ \\
\hline
\end{tabular}


DOI: $10.17148 / I A R J S E T .2021 .8523$

\begin{tabular}{|c|c|c|}
\hline & & $\begin{array}{l}\text { - Carrying out project work in accordance with applicable standards and } \\
\text { does not cause any damage to the environment and surrounding } \\
\text { facilities }\end{array}$ \\
\hline & $\begin{array}{l}\text { Non-Governmental } \\
\text { Organization } \\
\text { opposing and } \\
\text { provoking residents }\end{array}$ & $\begin{array}{l}\text { - Involving local companies and human resources from the region as a } \\
\text { partners in accordance with their qualifications } \\
\text { - Empowering the communities around the project site through } \\
\text { community development program or partnership and community } \\
\text { development programs }\end{array}$ \\
\hline & $\begin{array}{l}\text { Delays in licensing } \\
\text { process }\end{array}$ & - Enhancing cooperation with local governments or related parties \\
\hline Economical & $\begin{array}{l}\text { Changes in } \\
\text { economic policy }\end{array}$ & $\begin{array}{l}\text { - Conducting negotiation with policy-makers regarding policy changes. } \\
\text { For example, if the gas price is reduced to USD } 6 \text { / MMBTU for a } \\
\text { particular industry, the company can propose an incentive option } \\
\text { through the application of special price for gas that bought from the } \\
\text { supplier to distribute to those particular industries }\end{array}$ \\
\hline \multirow[b]{2}{*}{ Organizational } & $\begin{array}{l}\text { Incompetent of the } \\
\text { labour }\end{array}$ & $\begin{array}{l}\text { - Recruiting certified workers and placing the workers according to their } \\
\text { expertise. }\end{array}$ \\
\hline & $\begin{array}{l}\text { Bad communication } \\
\text { (Example : lack of } \\
\text { coordination } \\
\text { meetings, language } \\
\text { differences, etc.) }\end{array}$ & $\begin{array}{l}\text { - Improving communication by conducting weekly meetings, and regular } \\
\text { reporting on project progress } \\
\text { - Ensuring to use a language that can be understood by all workers }\end{array}$ \\
\hline \multirow[t]{2}{*}{ Investment } & $\begin{array}{l}\text { Decreasing gas } \\
\text { demand by } \\
\text { consumers }\end{array}$ & $\begin{array}{l}\text { - Managing cost-efficiency in terms of operations and maintenance while } \\
\text { still concern to safety aspects }\end{array}$ \\
\hline & $\begin{array}{l}\text { Increasing loan } \\
\text { interest rates }\end{array}$ & $\begin{array}{l}\text { - Making an agreement from the beginning related to making the interest } \\
\text { rate flat }\end{array}$ \\
\hline \multirow{5}{*}{ Technological } & $\begin{array}{l}\text { Poor welding } \\
\text { quality }\end{array}$ & $\begin{array}{l}\text { - Recruiting certified and competent experts in welding work } \\
\text { - Conducting direct supervision in the field }\end{array}$ \\
\hline & $\begin{array}{l}\text { Errors in work that } \\
\text { results in doing a } \\
\text { re-work }\end{array}$ & $\begin{array}{l}\text { - Improving coordination, regular reporting and direct supervision in the } \\
\text { field }\end{array}$ \\
\hline & $\begin{array}{l}\text { The existence of } \\
\text { additional materials } \\
\text { or equipment that } \\
\text { takes a long time in } \\
\text { delivering }\end{array}$ & $\begin{array}{l}\text { - Doing the reengineering process earlier } \\
\text { - Improving communication with suppliers }\end{array}$ \\
\hline & $\begin{array}{l}\text { Difficult access to } \\
\text { project site }\end{array}$ & $\begin{array}{l}\text { - Conducting a survey in advance of site project area, so the access can } \\
\text { be planned and built }\end{array}$ \\
\hline & Design changes & $\begin{array}{l}\text { - Conducting surveys, ensuring that matters related to implementation } \\
\text { standards such as technical drawings, specifications, equipments and } \\
\text { materials used are clear, without any changes } \\
\text { - Involving contractors in the planning process }\end{array}$ \\
\hline \multirow{3}{*}{$\begin{array}{l}\text { Safety \& } \\
\text { Security }\end{array}$} & $\begin{array}{l}\text { Criminal acts } \\
\text { (Vandalism, theft, } \\
\text { extortion, etc) }\end{array}$ & $\begin{array}{l}\text { - Increasing security level by placing special security officers } \\
\text { - Tightening access and prohibiting other parties from entering the project } \\
\text { area } \\
\text { - Sterilizing the project area from unauthorized parties. }\end{array}$ \\
\hline & $\begin{array}{l}\text { Accident during } \\
\text { construction }\end{array}$ & $\begin{array}{l}\text { - Providing socialization of work procedures to workers related to the } \\
\text { construction process } \\
\text { - Performing safety induction before work } \\
\text { - Conducting daily safety evaluations after finishing work } \\
\text { - Equipping workers with personal protective equipment } \\
\text { - Assigning an HSE supervisor }\end{array}$ \\
\hline & $\begin{array}{l}\text { Leakage in pipelines } \\
\text { due to corrosion }\end{array}$ & $\begin{array}{l}\text { - Covering pipelines to protect from direct contact with the environment } \\
\text { - Performing periodic checks inside the pipeline using the intelligent } \\
\text { pigging method } \\
\text { - Using gas pipelines in accordance with the standard }\end{array}$ \\
\hline
\end{tabular}




\section{DOI: $10.17148 / I A R J S E T .2021 .8523$}

\begin{tabular}{|c|c|c|}
\hline & $\begin{array}{l}\text { Damage to pipeline } \\
\text { facilities during } \\
\text { operation caused by } \\
\text { external parties (For } \\
\text { example: pipe leaks } \\
\text { due to excavation) }\end{array}$ & $\begin{array}{l}\text { - Providing information and knowledge to the communities around the } \\
\text { gas pipeline } \\
\text { - Providing a sign that indicating the existence of pipeline around the gas } \\
\text { pipeline area }\end{array}$ \\
\hline & $\begin{array}{l}\text { Accident during } \\
\text { operational and } \\
\text { maintenance }\end{array}$ & $\begin{array}{l}\text { - Providing training equipped with a competency test at the end of the } \\
\text { training session to each gas pipeline operational operator. } \\
\text { - Carrying out tasks in accordance with the applicable Standard } \\
\text { Operational Procedures (SOP) during the operational and maintenance } \\
\text { period }\end{array}$ \\
\hline & $\begin{array}{l}\text { Accidents on public } \\
\text { roads during } \\
\text { mobilization }\end{array}$ & $\begin{array}{l}\text { - Overseeing personnel performance and enacting personnel exchange if } \\
\text { others experience a decrease in performance (tired, lack of } \\
\text { concentration, etc) } \\
\text { - Checking vehicles condition that will be used to transport equipment or } \\
\text { personnel to the project site } \\
\text { - Running the applicable Standard Operating Procedure (SOP) }\end{array}$ \\
\hline \multirow[b]{2}{*}{$\begin{array}{l}\text { Natural \& } \\
\text { Disaster }\end{array}$} & Earthquake & - Using an earthquake-based design \\
\hline & Landslide & $\begin{array}{l}\text { - Identifying prone area to landslides, and selecting relocation area with } \\
\text { the least risk of landslides } \\
\text { - Improving and maintaining good drainage around the pipeline location }\end{array}$ \\
\hline \multirow[t]{2}{*}{ Environmental } & $\begin{array}{l}\text { Damage to existing } \\
\text { infrastructure } \\
\text { underground (Fiber } \\
\text { optic cable, power } \\
\text { cable) }\end{array}$ & $\begin{array}{l}\text { - Searching for information about the presence of existing infrastructures } \\
\text { around the project site }\end{array}$ \\
\hline & $\begin{array}{l}\text { Environmental } \\
\text { pollution }\end{array}$ & $\begin{array}{l}\text { - Creating waste management plan and provide a place for residual waste } \\
\text { disposal }\end{array}$ \\
\hline
\end{tabular}

B. Potential Cost Savings by Relocating Gas Pipeline

Total investment cost incurred to relocate a 12-inch diameter gas pipe with a relocation length of about $2.5 \mathrm{~km}$ is USD $1,600,660$. However, this total investment cost is more economical than the potential losses that could occur if gas pipeline is not relocated. In this case if gas pipeline is not relocated, and assumed that there is only one damage occurs per year at each of crossing points (six crossing points), and requires seven days repaired time of each, so the gas pipeline cannot be operated temporarily, then the potential loss can reach up to USD 55.223 per year. This potential loss can continue to increase considering that the amount of gas being distributed currently is only around $4 \%$ of the total available capacity. Thus by relocating the gas pipeline, this potential loss can be eliminated. In addition, if the gas pipeline is relocated but the risks are not mitigated, then with a moderate risk status, will cause a potential loss of $20 \%$ of the investment cost, which is around USD 320.132. Although risk mitigation requires an additional cost of USD 45.596, however, these costs can eliminate this potential loss thus providing a potential cost savings of USD 274.536.

TABLE IIIII POTENTIAL LOSSES IF GAS PIPELINES ARE NOT RELOCATED

\begin{tabular}{|c|c|c|c|}
\hline No & Information & Amount & Unit \\
\hline \multirow[t]{5}{*}{1} & Assumed number of days for pipeline restoration in case of damage & & \\
\hline & Number of crossing points & 6 & \\
\hline & Assumed number of days required for recovery & 7 & Days \\
\hline & Assumption the number of events in 1 year at each crossing point & 1 & Times / Year \\
\hline & Total days of recovery & 42 & Day / Year \\
\hline \multirow[t]{6}{*}{2} & Losses from gas delivery & & \\
\hline & Gas volumes & 1533 & $\mathrm{MSCF} / \mathrm{D}$ \\
\hline & Toll Fee & 0,66 & USD / MSCF \\
\hline & The amount of losses per day & 1012 & USD / Day \\
\hline & The amount of losses per year & 42.495 & USD / Year \\
\hline & Commercial losses from gas sales & & \\
\hline
\end{tabular}




\section{International Advanced Research Journal in Science, Engineering and Technology}

Vol. 8, Issue 5, May 2021

DOI: $10.17148 / I A R J S E T .2021 .8523$

\begin{tabular}{|c|c|c|}
\hline Gas volumes & 1595 & MMBTU / D \\
\hline Gas sales margin & 0,19 & USD / MMBTU \\
\hline The amount of losses per day & 303 & USD / Day \\
\hline The amount of losses per year & 12.728 & USD / Year \\
\hline Total Losses & 55.223 & USD / Year \\
\hline
\end{tabular}

\section{IV.CONCLUSION}

The results of risk analysis indicate that the risk on this gas pipeline relocation as a whole has a moderate risk status, with safety \& security being the risk category with the highest risk status. Relocating this gas pipeline, even though requires an investment cost of USD 1.600.660, however, this cost can eliminate potential losses up to USD 55.223 per year, which can continue to increase because the amount of gas currently flowed through the gas pipeline is only around $4 \%$ of the total pipeline capacity. In addition, the mitigation cost of USD 45.596 required to mitigate 23 risk variables can eliminate potential losses of USD 320.132 if gas pipeline is relocated but the risks are not mitigated. Thus this can provide a potential savings of USD 274.536.

\section{REFERENCES}

[1]. Atmajaya, H. K., Mahali, K., (2015) "Pengaruh Peningkatan Infrastruktur terhadap Pertumbuhan Ekonomi di Kota Sibolga", Jurnal Ekonomi dan Keuangan, Vol. 3, No. 4.

[2]. Cornwell, J. B., Martinsen, W. E., Johnson, D. W., (1989) “Risk Analysis Methodology for Gas Pipelines", Paper presented at Petro Safe '89, Houston, Texas.

[3]. Kirchhoff, D., Doberstein, B., (2006) “Pipeline risk assessment and risk acceptance criteria in the State of São Paulo, Brazil”, Impact Assessment and Project Appraisal, Vol. 24, No. 3, pp 221-234.

[4]. C. Miao, J. Zhao, (2012) "Risk Analysis for the Urban Buried Gas Pipeline with Fuzzy Comprehensive assessment method, :J. Press. Vessel Technol. Vol. 134, No. 2.

[5]. Mubin, S. \& Mubin, G., (2008) "Risk Analyst for Construction and Operation of Gas Pipeline Project in Pakistan", Pakistan Journal of Engineering and Applied Science, Vol. 2, pp 22-37.

[6]. Prabowo, I. \& Moses, L., (2009) "Manajemen Risiko Pada Proyek Relokasi Pipa 28 inch PT. Pertamina Gas Area Jawa Bagian Timur", Prosiding Seminar Nasional Manajemen Teknologi X, pp A-13-1 - A-13-8.

[7]. Bogucki, M., Polonski, M., (2019) "Risk Analysis for High Pressure Gas Pipeline Construction Schedule", IOP Conference Series : Material Science and Engineering, Vol 471112042.

[8]. Shah, R. J., Matipa, W., Kraidi, L., Borthwick, F., (2018) “An Analysis of the Crucial Risk Factor in Oil and Gas Pipeline Project Using a Comprehensive Risk Management Framework", Conference : A productive Relationship : Balancing Fragmentation and Integration, ARCOM 2018: 34 th Annual Conference.

[9]. Ćurčić, M., Petronic, S., (2020) "Protection of Pipelines From Terrorist Attack", Security Dialogues Scientific Article, pp 231-243.

[10]. Biezma, M., Andres, M., Agudo, D. \& Briz, E., (2020) "Most Fatal Oil \& Gas Pipeline Accident Through History: A Lessons Learned Approach", Engineering Failure Analysis on Elsevier, Vol. 110, pp 1-14.

[11]. Nnadi, U., Hassan, Z., Smyth, D., Mooney, J., (2014) "Lack of Proper Safety Management Systems in Nigeria Oil and Gas Pipelines", IChemE : The Institution of Chemical Engineers, Sysmposium Series No. 159.

[12]. Project Management Institute, (2013) “A guide to the Project Management Body of Knowledge (PMBOK guide) (5 $5^{\text {th }}$ ed.) ", Project Management Institute.

[13]. Bafle, N., Chiara, M., McAleer, B., Rocke, M., (2014) “Safety Risk Registers : Challenges and Guidance”, Chemical Engineering Transactions, Vol. 36, pp 571-576.

[14]. D’Appolonia, E., (1979) Proc. Of $9^{\text {th }}$ International Conference on Soil Mechanic and Foundation Engineering, Tokyo, Japan, Vol. 4, pp 410414.

[15]. Rosyid, D. M., Jamil, M. Y., Wahyudi, (2017) “Risk Assessment of Onshore Pipeline in Gresik Area”, International Journal of Offshore and Coastal Engineering, Vol. 1, No.1 pp $29-34$.

[16]. Altenbach, T., Brereton, S., (1998) "Risk Ranking Methodology for Chemical Release Events", International Conference on Probabilistic Safety Assessment and Management, New York City.

[17]. Markowski, A. S., Mannan, M. S., (2008) "Fuzzy Risk Matrix", Journal of Hazardous Materials, pp 152 - 257.

[18]. Cox, L. A., (2008) “What is Wrong With Risk Matrices?”, Risk Analysis, Vol. 28, No. 2.

[19]. Muhlbauer, W., (2004) Pipeline Risk Management Manual (3 ${ }^{\text {rd }}$ Edition), Gulf Professional Publishing.

[20]. Saltelli, A., Tarantola, S. \& Campolongo, F., (2000) "Sensitivity Analysis as an Ingredient of Modelling”, Statistical Science, Vol. 4, No. 2, pp 377-395.

[21]. Septiani, H., Agung, W., Syarifudin. (2015) “Aplikasi Manajemen Risiko pada Pembangunan Sistem Penyediaan Air Minum (SPAM) Regional Jawa Tengah (Studi Kasus pada Pembangunan Jaringan Transmisi SPAM Regional Bregas)", Jurnal Media Komunikasi Teknik Sipil, Vol. 21, No. 2, pp123-132.

[22]. Gajewska, E., Mikaela, R., (2011) "Risk Management Practice in a Construction Project - a case study", Thesis : Department of Civil and Environmental Engineering, Chalmers University of Technology, Sweden.

[23]. Wideman, M. R., (1992) "Project and Program Risk Management : A Guide to Managing Project Risk Opportunities", Project Managemen Institute.

[24]. Nursetyo, G., (2015) “Kajian Manajemen Risiko Bisnis Jasa Konstruksi”, Jurnal Teknik Sipil dan Arsitektur”, Vol. 16, No. 20.

[25]. Kolmalski, S., Józef, M., (2019) "Risk Factor in a Process of Gas Supply Pipeline Construction”, MATEC Web of Conferences, Vol. 262, pp 16 